IZA DP No. 5045

Crisis, What Crisis?

Patterns of Adaptation in European Labor Markets

Werner Eichhorst

Michael Feil

Paul Marx

July 2010 


\title{
Crisis, What Crisis? Patterns of Adaptation in European Labor Markets
}

\author{
Werner Eichhorst \\ IZA
}

\section{Michael Feil}

$I A B$

\author{
Paul Marx
}

$I Z A$

\section{Discussion Paper No. 5045}

July 2010

IZA

P.O. Box 7240

53072 Bonn

Germany

Phone: +49-228-3894-0

Fax: +49-228-3894-180

E-mail: iza@iza.org

Any opinions expressed here are those of the author(s) and not those of IZA. Research published in this series may include views on policy, but the institute itself takes no institutional policy positions.

The Institute for the Study of Labor (IZA) in Bonn is a local and virtual international research center and a place of communication between science, politics and business. IZA is an independent nonprofit organization supported by Deutsche Post Foundation. The center is associated with the University of Bonn and offers a stimulating research environment through its international network, workshops and conferences, data service, project support, research visits and doctoral program. IZA engages in (i) original and internationally competitive research in all fields of labor economics, (ii) development of policy concepts, and (iii) dissemination of research results and concepts to the interested public.

IZA Discussion Papers often represent preliminary work and are circulated to encourage discussion. Citation of such a paper should account for its provisional character. A revised version may be available directly from the author. 
IZA Discussion Paper No. 5045

July 2010

\section{ABSTRACT}

\section{Crisis, What Crisis? Patterns of Adaptation in European Labor Markets ${ }^{*}$}

The current crisis, while of a global nature, has affected national labor markets to a varying extent. While some countries have experienced a steep increase in unemployment, employment in other developed economies has not fallen in parallel with a significant decline in GDP. Our analysis shows that labor market institutions frequently used to study employment performance can explain the development of unemployment in the situation of crisis in some clusters of countries much better than in others. One major factor to be incorporated in capturing national variations is the role of internal flexibility, in particular working time adjustment. This calls for a broader concept of labor market flexibility which takes into account different channels of adjustment.

JEL Classification: J23, J21, J58

Keywords: labor market institutions, internal flexibility, employment protection, economic crisis

Corresponding author:

Werner Eichhorst

IZA

P.O. Box 7240

53072 Bonn

Germany

E-mail: eichhorst@iza.org

\footnotetext{
* The authors thank Tim Schwarzmüller and Max Sties for their research assistance, as well as Antje Mertens for her insightful suggestions. Any remaining errors are our own.
} 


\section{Introduction}

Although the current crisis is global, the effects felt by the national labor markets have varied to different degrees: some countries have witnessed a rapid rise in unemployment; others have not experienced the same fall in unemployment as in GDP. Particular countries with more regulated labor markets and developed instruments for internal flexibility have so far seemed to be better prepared to contain job losses, as the recent debate about the German "labor market miracle” shows (Möller 2010).

Hence, among other factors such as the structure of the economy or macro-economic policies, labor market institutions are expected to help explain cross-country differences. This paper addresses the topic of institutional determinants of labor market adjustment from two different perspectives: first, we review existing research on the role of shocks and institutions and try to replicate previous econometric findings with new data. This is justified by a number of new indicators which have become available over recent years. Second, we suggest a new measure for labor market flexibility. This helps us to understand which role different institutional frameworks play in determining labor market performance in both the short and long run.

The empirical part is based on both quantitative work covering the EU and OECD countries as well as on an in-depth analysis of selected national cases. The quantitative part uses standard indicators for external labor market flexibility. It shows that this set of factors can explain the development of unemployment in earlier crises and accounts for some variation of unemployment in the most recent period. However, since the explanatory power decreases for more recent data, a full understanding of current adjustment processes obviously requires a broader picture of labor market flexibility. In particular, enterprise-level strategies regarding working time adjustment and ad-hoc policy interventions 'bias' the expected impact of institutions on short-term performance. This effect is arguable stronger in the current crisis, which led most policy makers in affluent economies to stabilize the labor market, e.g., by bailing-out vulnerable sectors. We therefore include case studies that account for hard-to-measure aspects of labor market flexibility, such as working time accounts and government sponsored adjustment.

\section{Labor Market Institutions and Labor Market Adjustment}

Labor market institutions are an important variable in explaining divergent labor market developments across countries and over time. The European phenomenon of persistent mass unemployment following the 'golden' postwar era shifted the focus of comparative labor market analysis. Instead of shocks, institutional rigidities were increasingly regarded as explanatory factors for employment outcomes (Blanchard 2006). Since the 1990s, institutions have been at the core of the debate about varying national labor market patterns. A large number of theoretical and empirical studies suggest, at least partly, a causal relation between institutional arrangements and labor market performance (Nickell 1997, 
Nickell et al. 2005, Bassanini and Duval 2006). It is argued that adverse institutions lead to a persistent deviation from labor market equilibria by distorting price- and wagesetting mechanisms, which take more time to adjust (Layard et al. 1991 and 2005). In this sense, four groups of labor market institutions are typically accused of creating or increasing unemployment: the wage-setting arrangement, unemployment benefits, taxation, and employment protection. Active labor market policies form a fifth group of institutions with significant (yet beneficial) influence on employment outcomes. Research into the interaction of institutions and shocks (Blanchard and Wolfers 2000, Bassanini and Duval 2006) aims at increasing the explanatory power as institutions influence both the speed of labor market adjustment as well as the persistence of labor market imbalances. Shocks tend to produce persistent unemployment if there is wage rigidity, a generous benefit system, and few effective activation policies (see also Bassanini and Duval 2009).

Yet another strand of literature emphasizes interactions between institutions and thereby paints a more complex picture of their macroeconomic and labor market effects. Institutional complementarities can explain why more regulated types of labor markets can produce favorable outcomes despite their rather 'inflexible' institutions (Hall and Soskice 2001, Amable 2003). Starting from the observation that institutional factors do not work in isolation but form complex institutional arrangements, typologies of employment systems assume that diverging but coherent models could have potentially equal capacities to generate favorable employment outcomes. This work has so far been mainly theoretical, and empirical contributions often aim at identifying national patterns rather than providing econometric evidence for their labor market impact. Modeling complex institutional networks and understanding their impact on macroeconomic or labor market performance remains a challenge for comparative research. However, there are empirical findings that indeed suggest a multi- or at least dual-peaked landscape rather than one superior model outperforming the rest (Freeman 2000, Bassanini/Duval 2006).

In this paper, we would like to complement the debate on labor market flexibility by pointing attention to some often neglected variables: in our understanding, focusing on 'classical' institutions determining external flexibility risks neglecting important aspects of flexibility. To fully understand national institutional patterns, the analysis has to be extended to additional factors. The most important one is education (including earlychildhood education, vocational training, and life-long learning). Another blind spot of most research is internal flexibility. This leads to biased results, as in many countries flexible working time models provide a compensation for rigid hiring-and-firing practices. Besides working time, organizational aspects make a major contribution to internal flexibility. Versatile workers provide an opportunity to respond to changing external conditions without drawing on resources from the external market. A note of caution, however, has to be made regarding the robustness of most findings. In general, one can argue that this type of research is less suitable for regression analysis since it most often relies on complex institutional analyses with strong qualitative evidence, which can be seen as less rigorous in empirical terms (Howell et al. 2007).

Thus, we can assume that a sufficient degree of flexibility is needed for good employment performance - but this flexibility can be achieved in various ways. While there may be 
similar overall employment rates, different patterns of flexibility can be associated with diverging distributional outcomes - and different paths in coping with the crisis both in the short and long run.

\section{Mapping Patterns of Labor Market Flexibility}

In order to capture different patterns of labor market flexibility in OECD countries, we refer to a widely used typology developed by Atkinson (1985). It is based on two distinctions: first, it differentiates between internal and external flexibility, i.e., strategies which are applied inside a company or to the outside labor market, respectively; second, flexibility either derives from variation of workload (numerical) or from organizational adaptability (functional). A third way is to adjust wages and labor costs to the economic situation. Considering these criteria, five types of flexibility can be distinguished:

(1) External numerical flexibility means the possibility to adapt the number of employees to the economic situation through layoffs or hiring (permanent or temporary). Determinants of external numerical flexibility are the extent of employment protection and the quantitative availability of manpower. The latter is influenced by features of the benefit system influencing labor supply. The same is true for taxation. High tax wedges and marginal effective tax rates can lead to several 'traps' that provide incentives to remain inactive, unemployed or in a low-paid job.

(2) Internal numerical flexibility is achieved without variations in the number of staff. It allows for adjustment of working time in order to meet a company's current utilization rate.

(3) External functional flexibility requires a skilled labor force adaptable to structural changes. Skill mismatch in the labor market can be avoided by promoting occupational mobility through active labor market policies, in particular job placement and training. A prerequisite for an adaptable labor force is the provision of appropriate primary, secondary, and tertiary education.

(4) Internal functional flexibility means the ability to react to changing demand with a flexible organization of the production process. This requires broad and well-educated employees able to perform different tasks. Thus, investment in firm-specific human capital via continual (internal) qualification makes a major contribution to this type of flexibility.

(5) Wage flexibility is when real wages can respond to changing macroeconomic conditions such as shocks. Wage rigidities result from features of a wage-setting regime such as statutory or collectively agreed minimum wages.

As can be seen from the discussion above, Atkinson's flexibility types are determined by various institutional factors. In our analysis we include eight groups of indicators than can be used as proxies for real-world institutional complexities (see Eichhorst et al. 2008 for a more detailed discussion).

1. Wage setting 
2. Unemployment benefits

3. Taxes on labor

4. Employment protection

5. Active labor market policies

6. Education and training

7. Working time arrangements

8. Human capital investment in a firm-specific setting

Based on a systematic aggregation of these institutional parameters, an overall indicator of labor market flexibility (see Annex 2) as well as a typology of countries can be established (for methodological details see also Eichhorst et al. 2009). Figure 1 provides the most recent institutional information on OECD countries regarding external and wage flexibility with the Anglo-Saxon countries and Switzerland, but also Denmark, at the top.

\section{Figure 1: Aggregate flexibility indicator (Version 1: External and wage flexibility, 2007)}

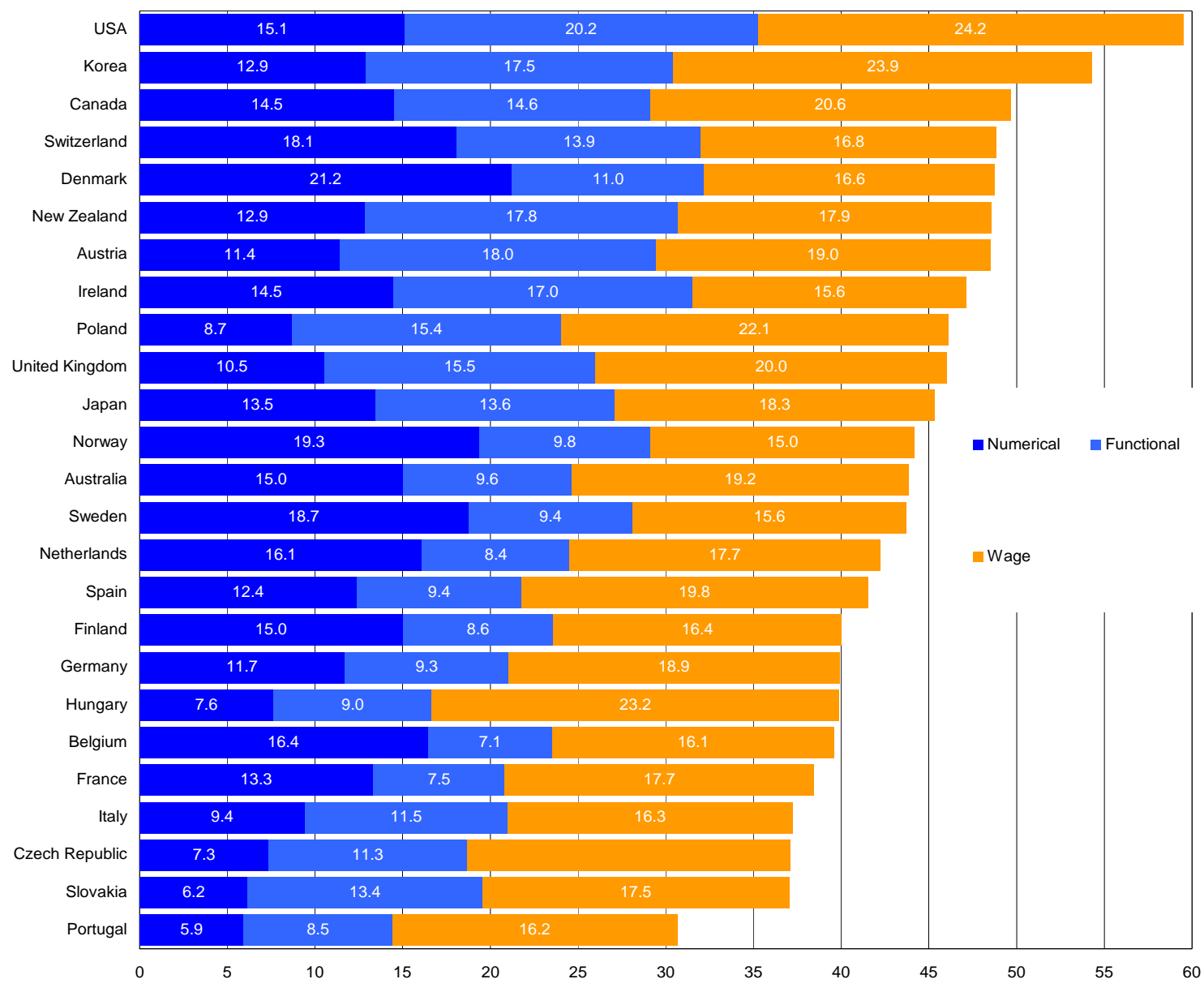


Figure 2 also incorporates information on internal flexibility. Due to data limitations this is restricted to the EU and 2003. This version of the indicator shows the extent to which different flexibility options are available in European countries. Each country has several options, but both the overall aggregate level and the structure of flexibility varies across countries. Germany, for example, stands out as a champion in internal numerical flexibility (working time); whereas the UK shows much larger external numerical and wage flexibility. Denmark seems to provide a full range of flexibility channels; whereas in Southern Europe flexibility is more restricted (except for temporary employment).

Figure 2: Aggregate flexibility indicator (Version 2: Internal, external and wage flexibility, 2003)

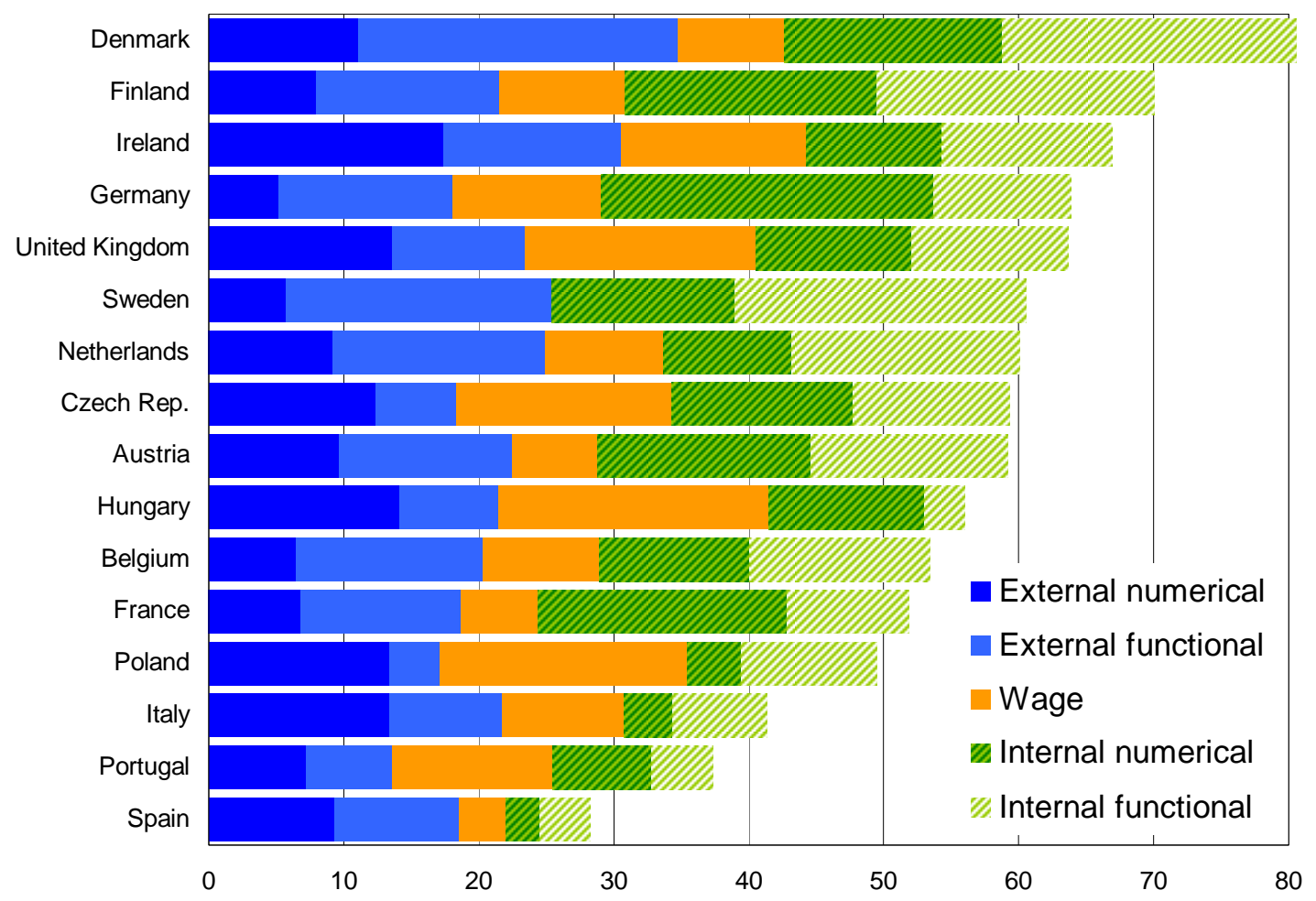

Based on this indicator, clusters with similar patterns of flexibility can be formed. The groupings strongly resemble established typologies (Figure 3 ). The first cluster can be labeled 'education-based' and comprises nine Scandinavian and Continental-European countries. It is characterized by low external numerical and wage flexibility, while external functional flexibility is high. The second cluster (Asian and the Anglo-Saxon countries) combines high external numerical and wage flexibility with intermediate external functional flexibility and can be called 'market-oriented l'. The third group consists of the four CEE countries, which have high external functional and wage flexibility but very low exter- 
nal functional flexibility ('market-oriented II'). Finally, the Southern European countries find themselves in a cluster which is characterized by rather low flexibility in all dimensions ('low flexibility cluster').

Figure 3: Cluster Tree external/wage flexibility, 2003 (hierarchical cluster analysis, dendrogram using ward method)

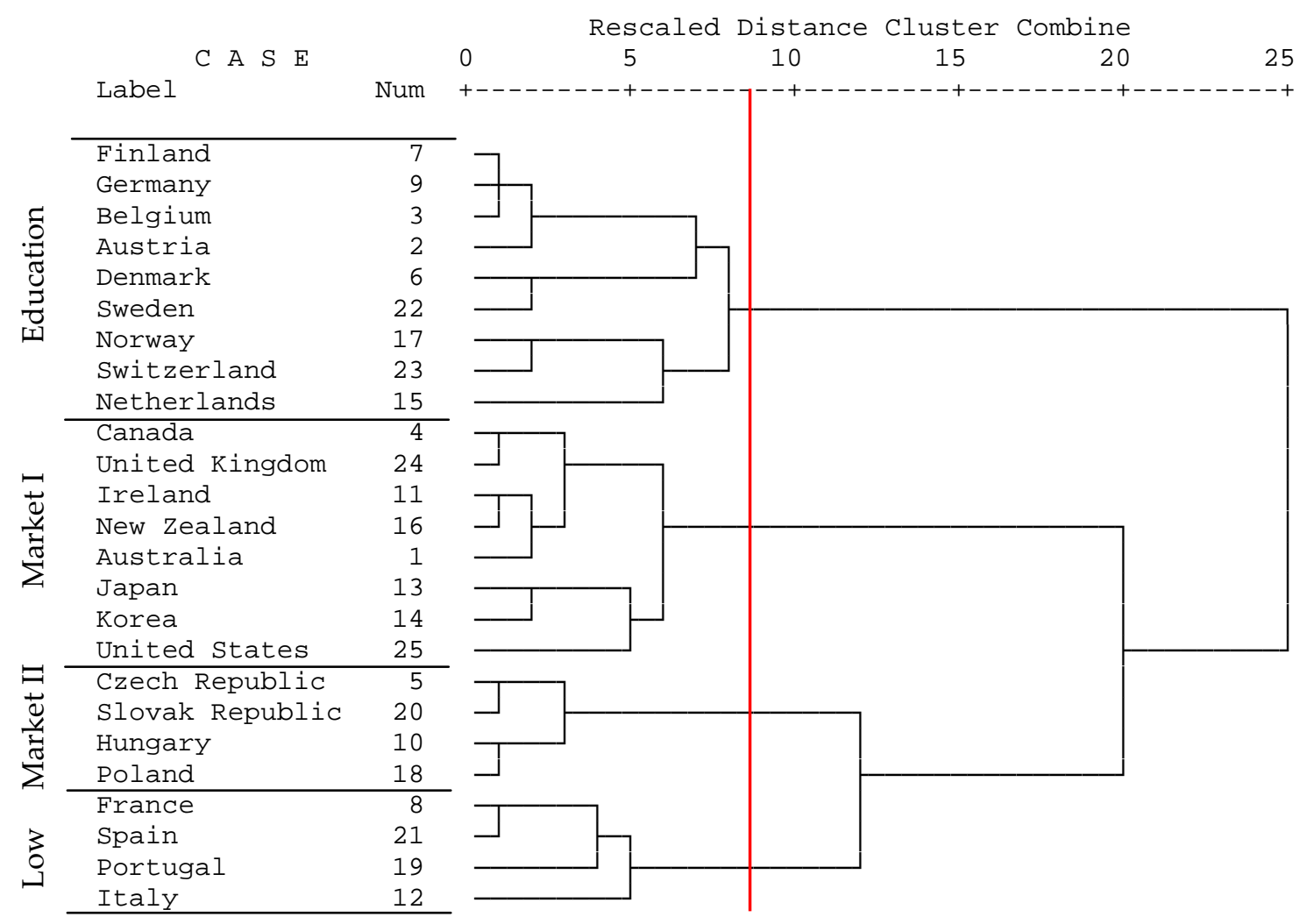

Results of the second cluster analysis including internal flexibility are reported in Figure 4. As for external flexibility, Continental and Scandinavian countries are quite similar, although Denmark and Sweden have to be treated as a separate cluster. Both exhibit strong internal flexibility, while internal functional flexibility prevails. Overall, functional elements (internally and externally) are very important in Denmark and Sweden, and so their cluster is termed 'functional model'. The remaining Scandinavian countries, together with the Continental ones, form the second cluster. They are characterized by an extensive use of working time arrangements (especially Finland, France, and Germany), but only by intermediate functional flexibility. In the third cluster, internal flexibility is clearly underdeveloped. It is formed by three Southern European countries ('low flexibility model'). The fourth cluster consists of cases that reveal very high external and wage flexibility and is therefore labeled 'market model'. The heterogeneous group comprises two Anglo-Saxon and three CEE countries. Contrary to what one might expect, most of these countries do 
not completely eschew internal flexibility but, instead, show an average level for both subindicators.

Figure 4: Cluster Tree overall flexibility, 2003 (hierarchical cluster analysis, dendrogram using ward method)

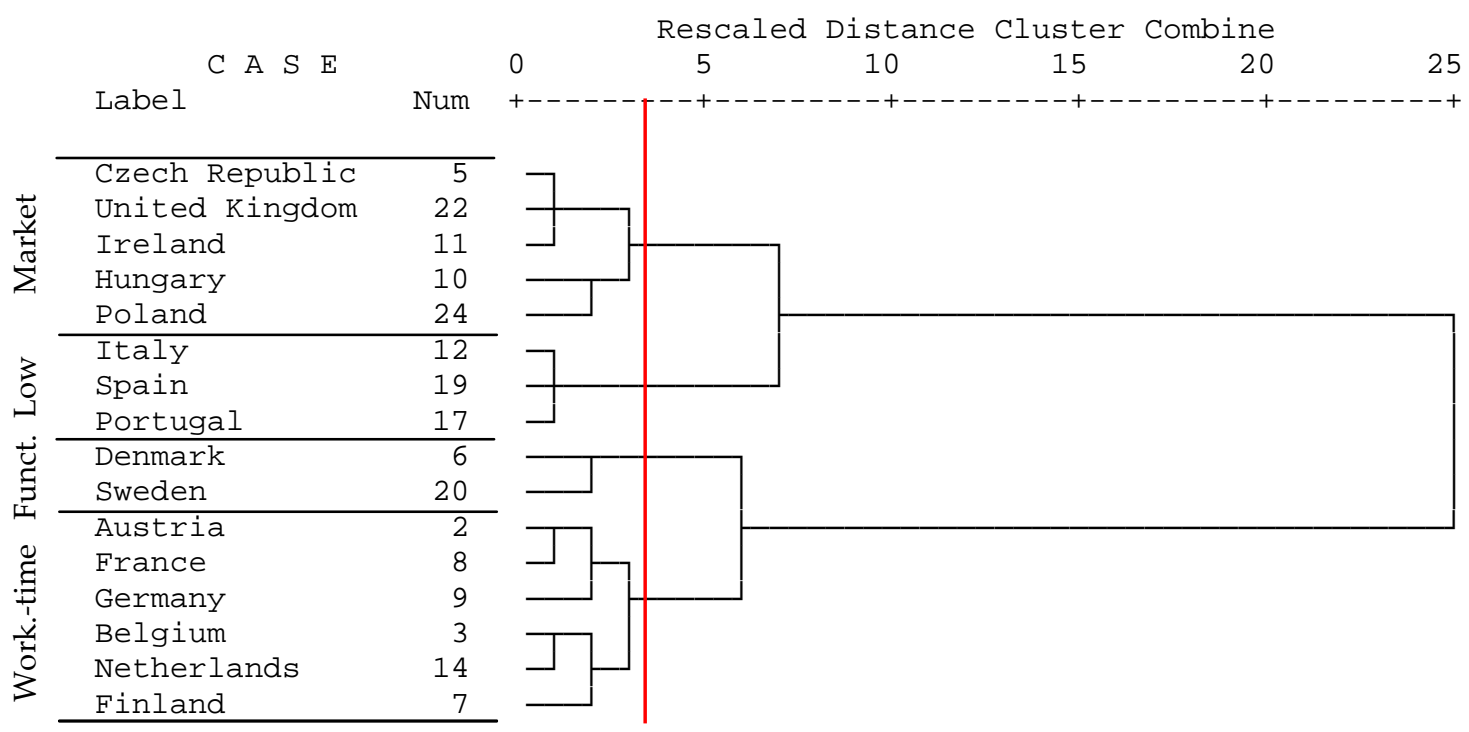

\section{Different Models of Flexibility and the Current Crisis}

OECD member states have been hit differently by the economic crisis. There are even a few countries which did not suffer a drop of GDP (Australia, Poland, and South Korea). Figure 5 relates changes in GDP to changes in employment. GDP growth rates per se, however, have to be analyzed with care, since they do not reflect the deviation from trend growth. Controlling for differences in trend growth rates, however, does not change the pattern very much. Comparisons with historic recessions after 1960 show that the drop in output has not been unprecedented in countries like the US, Japan, or Italy, where the first oil price shock resulted in a larger absolute deviation of actual from trend GDP than the latest financial turmoil. A look at the change of GDP to trend growth ratio, however, reveals that the economic and financial crisis is rather prominent. ${ }^{1}$ In any case, there is considerable divergence in the relation between GDP and employment in the current crisis, as Figure 5 shows.

\footnotetext{
${ }^{1}$ We use a standard Hodrick-Prescott filter to derive trend growth rates. Möller (2010: 328) applies the same method for Germany only.
} 
Figure 5: Decline in employment and GDP between country-specific peaks before the crisis and third quarter of 2009

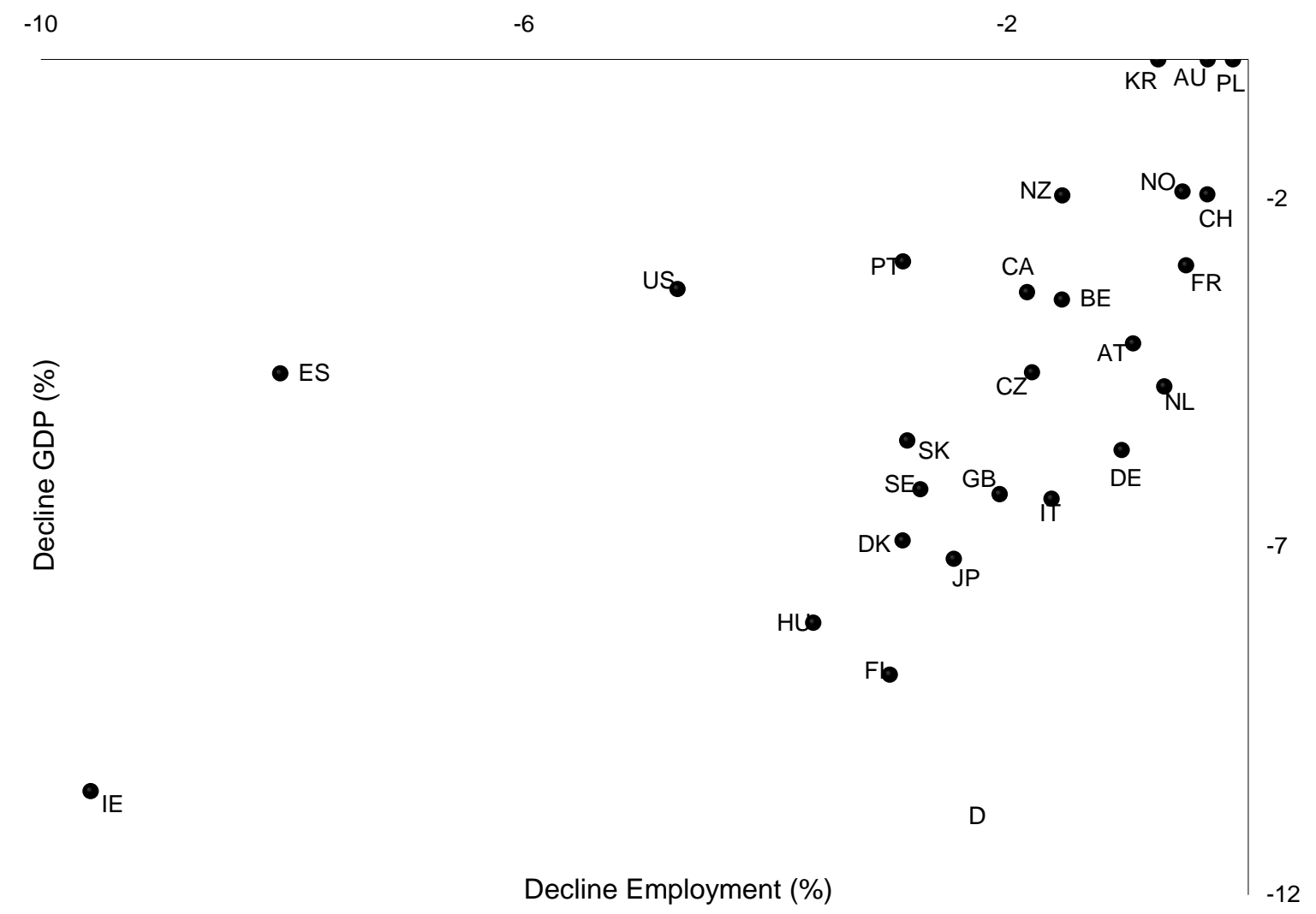

Source: OECD.

A two-tier pattern of employment-GDP changes emerges from Figure 5. A larger group below an imaginary $45^{\circ}$-degree line shows rather moderate employment losses. The champions in preserving employment in the crisis at this particular snapshot are Germany and the Netherlands. On the other hand, the big exceptions in this respect are Portugal, the US, Spain and Ireland.

Obviously, we have to be aware of the fact that the impact of the crisis on labor markets may not yet be fully apparent. So what looks like a miracle in the short run could still turn out to be rather normal in the medium term, since it simply takes different periods of time until national labor markets react. However, there has so far been little evidence that many countries of the 'small-reaction' group on the right in Figure 5 will follow the 'outliers' on the left.

A good starting point for our discussion of different adjustment patterns would be reliable figures on the volume of work throughout the OECD. The existing data is compiled in Table 1. To a large extent, changes in hours of work conditional on changes in GDP are small. Actually, the figures are quite puzzling. It is hard to believe that there are countries suffering from a large drop in GDP that have experienced constant or even slightly rising 
hours of worked. Whether the reasons for the differences between changes in GDP and changes in hours of worked are real or due to measurement error and timing problems cannot be solved here. It should be clear that a drop in GDP which is not matched by a similar reduction in total hours of work implies a large decrease in labor productivity. This is at odds with existing data showing only slow-downs in measures of productivity growth in economic downturns, as opposed to actual decreasing productivity figures, which are hard to find. This is not to say that there is no evidence of a fall in hourly labor productivity (Möller 2010: 334); but the gap appears simply to great to be explained by excessive labor hoarding.

Table 1 also presents the adjustments during the recent recession by clusters. First and foremost, the country groupings based on more long-standing institutional patterns are only to a limited degree meaningful in the short-term perspective. For most variables, there is more intra than inter-cluster variation. This holds true for GDP (which is not surprising), unemployment rate and employment (which is more puzzling). Unemployment reacts more swiftly in market-oriented countries; however, this is largely driven by Ireland. The heterogeneity within clusters points once again to the relevance of crisis-specific interventions, which obviously distort the effect of institutions. Where the clustering is more obvious is in the adjustment of temporary employment, since here (as expected) only education-based and southern 'Low Flex' cases show a notable reaction. Note that not only the usual suspects Spain and Italy rely on temporary workers as a flexibility source but that this path is also prevalent in the Scandinavian cases (except for Denmark). Regarding hours worked and wages, there is no clear pattern (although we clearly face a data problem here). 
Table 1: Adjustment by country and cluster. Percentage change from country-specific beginning of crisis (in terms of GDP) to last available data.

\begin{tabular}{|l|l|l|l|l|l|l|}
\hline Country & GDP & $\begin{array}{l}\text { Unempl. } \\
\text { rate }\end{array}$ & Empl. & $\begin{array}{l}\text { Temp. } \\
\text { empl. }\end{array}$ & $\begin{array}{l}\text { Hours } \\
\text { worked }\end{array}$ & $\begin{array}{l}\text { Hourly } \\
\text { earnings }\end{array}$ \\
\hline Australia & 0.6 & 36.3 & -0.1 & 0 & 0 & 0.2 \\
\hline Canada & -3.2 & 39.1 & -1.8 & 2.7 & 0 & -3.7 \\
\hline Ireland & -10.5 & 175.2 & -9.3 & -13.7 & -5.4 & 10.7 \\
\hline Japan & -7.2 & 39.9 & -2.2 & 0 & 0 & -6.7 \\
\hline Korea & 0.7 & 17.2 & 0.0 & 0 & 0 & -2.6 \\
\hline New Zealand & -2.0 & 84.3 & -1.4 & 0 & 0 & 4.9 \\
\hline United Kingdom & -6.0 & 51.9 & -1.9 & -0.8 & -1.5 & 2.3 \\
\hline USA & -3.3 & 81.7 & -4.6 & & & 3.5 \\
\hline Market-oriented I & $-\mathbf{3 . 9}$ & $\mathbf{6 5 . 7}$ & $-\mathbf{2 . 7}$ & $-\mathbf{1 . 7}$ & $\mathbf{- 1 . 0}$ & $\mathbf{1 . 1}$ \\
\hline Austria & -4.0 & 45.0 & -0.7 & 5.3 & -2.4 & 0.7 \\
\hline Belgium & -3.4 & 18.3 & 0.0 & -0.2 & -0.7 & 3.1 \\
\hline Switzerland & -2.0 & 31.7 & 0.5 & & & \\
\hline Denmark & -6.4 & 101.1 & -2.8 & 0.6 & -3.1 & 1.9 \\
\hline Finland & -8.8 & 33.2 & -3.5 & -18.0 & -1.6 & 3.3 \\
\hline Germany & -5.6 & -0.4 & -0.6 & -1.7 & -1.9 & 2.5 \\
\hline Netherlands & -4.7 & 29.4 & -0.7 & -0.8 & -1.7 & 3.7 \\
\hline Norway & -1.3 & 11.8 & -1.5 & -14.9 & -0.3 & 3.0 \\
\hline Sweden & -5.9 & 45.8 & -2.5 & -11.0 & & 1.2 \\
\hline Education-based & $-\mathbf{4 . 7}$ & $\mathbf{3 5 . 1}$ & $\mathbf{- 1 . 3}$ & $\mathbf{- 7 . 6}$ & $\mathbf{- 1 . 7}$ & $\mathbf{2 . 6}$ \\
\hline Czech Republic & -4.1 & 69.0 & -1.8 & 0.0 & -2.9 & 2.5 \\
\hline Hungary & -8.0 & 37.7 & -3.1 & 8.6 & -2.7 & 7.7 \\
\hline Poland & 1.0 & 21.7 & 0.3 & 4.4 & 0 & 1.9 \\
\hline Slovak Republic & -5.5 & 39.1 & -4.1 & -4.0 & & 3.7 \\
\hline Market-oriented II & $-\mathbf{4 . 2}$ & $\mathbf{4 1 . 9}$ & $\mathbf{- 2 . 2}$ & $\mathbf{2 . 3}$ & $\mathbf{- 1 . 9}$ & $\mathbf{4 . 0}$ \\
\hline Spain & -4.5 & 103.3 & -8.7 & -20.4 & 1.0 & 2.8 \\
\hline France & -3.0 & 25.8 & -0.8 & -6.1 & 0.3 & 3.6 \\
\hline Italy & -5.9 & 19.4 & -2.0 & -12.7 & -1.7 & 4.6 \\
\hline Portugal & -2.9 & 30.1 & -3.8 & -9.9 & 1.2 & -5.6 \\
\hline Low Flexibility & $-\mathbf{4 . 1}$ & $\mathbf{4 4 . 6}$ & $\mathbf{- 3 . 8}$ & $\mathbf{- 1 2 . 3}$ & $\mathbf{0 . 2}$ & $\mathbf{1 . 4}$ \\
\hline
\end{tabular}

Source: OECD. 


\section{Quantitative Analysis}

\subsection{Assessing the Role of Labor Market Institutions}

The basic idea for the kind of econometric research undertaken here stems from the 'shocks-and-institutions' literature, where the focus is on the equilibrium or structural unemployment rate. We explore here the extension of the framework to changes in actual unemployment rates. The reason for this is rather obvious: any statement about the role of labor market institutions in the current crisis could at best hold for the actual unemployment rate, since the equilibrium rate will clearly depend on the effects of the crisis. In a sense we are shifting the yardstick in the literature from a decent explanation of the medium-term development to the short run. For part of the literature, this may seem inappropriate. It has been argued (see Blanchard and Wolfers 2000, among others) that the slow movements of institutions only justifies a model in which all variables are averaged over a longer period of time, most commonly five years. Nickell et al. (2005) on the other hand use annual data. Baccaro and Rei (2007) discuss these alternative ways of assessing the influence of shocks and institutions. They estimate both types of models (with annual and five-year-averaged data) and conclude that there is little evidence supporting the deregulatory view.

An argument in favor of annual data and the short-run approach can be found in the interaction of shocks and institutions. If institutions shape labor market adjustments due to major changes in macroeconomic conditions, then their effects should show up in the short as well as the medium run. A typical example for this kind of reasoning is the role of employment protection. If existing jobs are well sheltered by strict labor laws, we will expect (un-)employment to react only slightly in response to adverse macroeconomic shocks. However, short- and medium-run effects could greatly differ if for instance strict employment protection prevents not only dismissals but also new hirings. Under these circumstances, one could expect deferred increases in unemployment and possibly similar medium-run effects more or less independent of differing labor market institutions.

An obvious approach to the problem of lagged adjustments would be the estimation of an error-correction model. This method, however, requires the existence of a cointegration relationship between unemployment rates, shocks and institutions. Individual and joint properties of these series become quite tricky in the context of a panel model. Panel unit root tests typically indicate that at least some of the unemployment series contain a unit root. On the other hand, shock and institutional variables are mostly found to be stationary. It is thus not very surprising that the existence of a cointegration relationship can hardly be proved by available tests for panel cointegration.

Another, although certainly simpler, way of dealing with the data is the estimation of models in first differences. This choice can be justified directly by non-stationarity and missing cointegration. Baccaro and Rei (2007) call the first-differencing strategy a 'safety device'. This is also our understanding. However, there is also a very substantial argument 
to use first differences, since our interest is mostly on changes in key labor market variables and much less on the long run. ${ }^{2}$ The models that we run should be understood as first attempts to see how much explanatory power there is in shocks and institutions. We do not try to maximize the fit of the models, nor do we try to minimize the prediction errors. Loosely speaking, we want to see what institutions can explain and what they cannot. Our hypotheses about the role of institutions is that in economies with rigid labor markets, adverse macroeconomic shocks lead to a smaller increase in unemployment than in economies with flexible labor markets. Our starting point is the model, expressed in equation (1): ${ }^{3}$

$$
\Delta u r_{i t}=\delta \Delta u r_{i, t-1}+\sum_{k} \beta_{k} x_{i t}^{k}+\sum_{l} \gamma_{l} z_{i t}^{l}+\sum_{m} \eta_{m} x_{i t}^{k} \cdot z_{i t}^{l}+a_{i}+\varepsilon_{i t}
$$

We allow for country fixed effects $\left(\alpha_{i}\right)$. We also experimented with time effects, which are usually interpreted as common unobserved shocks. Since for most of the years they turned out insignificant, we decided not to include them.

The model includes $\mathrm{k}$ macroeconomic (shock) variables $\left(x_{i t}\right)$, I labor market institutions $\left(z_{i t}\right)$ and $m=k \cdot l$ interaction terms of macro variables and institutions to pick up possible effects of institutions depending on macroeconomic conditions. We expect these interactions to be a function of the level of the institutions and not of their change. ${ }^{4}$

The data we use are closely related to those in Nickell et al. (2005). To some extent, we draw directly on their database. Most of the time series are taken from the OECD's Source Database. This holds for all macroeconomic and for most of the institutional variables. Information on bargaining coordination is taken from the ICTWSS: Database on Institutional Characteristics of Trade Unions, assembled by the Amsterdam Institute for Advanced Labour Studies (AIAS). We constructed all the shock variables according to Nickell et al. (2005) except for the TFP shock, where we follow Bassanini and Duval (2006). The underlying idea of data gathering was the production of time series covering a maximum period of time. To do this, we also made direct use of Nickell et al. (2005) data. This refers to cases in which time series stored at the OECD are shorter than those in the Labour Market Institutions Database underlying the Nickell et al. (2005) paper.

Our modeling strategy can be summarized as 'general to specific'. The model outlined in (1) is a rather general way of addressing the data. We consider five macroeconomic variables: output gap, total factor productivity (TFP) shock, labor demand shock, real interest rates, and a terms-of-trade shock. The institutions block also consists of five variables: benefit reduction rates (BRR), trade union density (TUD), employment protection (EP),

\footnotetext{
${ }^{2}$ Baccaro and Rei (2007: 550) also argue that the model in first differences is preferable because then there is no indication to include the lagged dependent variable, i.e., the first difference of the lagged unemployment rate. Our data does not completely confirm this argument, since we find for several specifications a significant coefficient for the lagged dependent variable. This is probably due to the fact that we use annual data as opposed to the five-year averages in Baccaro and Rei.

${ }^{3}$ Tested by xtserial and abar in Stata.

${ }^{4}$ We are aware of the possibility that interaction terms could be I(1). Standard unit roots tests, however, do not support this hypothesis.
} 
bargaining coordination (BC), and the tax wedge (TW). In the fully fledged version, this amounts to 35 coefficients to be estimated for the shocks, institutions, and interaction terms. Already from an ex-ante perspective this number appears fairly high. On the other hand, one should bear in mind that also interaction terms between institutions have been used in the literature (see e.g., Belot and van Ours 2001). Adding this kind of interactions would obviously increase the number of parameters to be estimated even further.

These early doubts about the number of independent variables were confirmed by running regressions with the full set of the complete variables or at least large subsets of them. Typical features of these models include large standard errors, wrongly signed coefficients and a general lack of robustness. We think that these problems can be traced back to a high degree of interdependence of the explanatory variables, or technically speaking, to some degree of multicollinearity. To cope with this issue, we resort to data-reducing methods. We use principal component analysis to reduce the number of shocks and institutions variables respectively to one. There is one exception on the institutions side. Since bargaining coordination is typically assumed to have a negative influence on unemployment, we do not include this variable in the institutions amalgam, consisting of the benefit replacement rate, trade union density and employment protection.

Table 2 reports our baseline estimates for the full sample using alternative methods. Due to existence of significant autocorrelation, which persists even if we include the lagged endogenous variable as a regressor, we run different type of feasible generalized least squares estimator. We also employ the method proposed by Beck and Katz (1995), i.e. OLS estimates with panel-corrected standard errors (PCSE), correcting for serial correlation $(\mathrm{AR}(1))$, heteroscedasticity and contemporaneously correlated errors across panels. The differences between the estimators turn out to be non-negligible, but qualitatively quite similar. The biggest difference is the estimated coefficient for the lagged unemployment rate, a finding that is perfectly in line with the different treatment of the data once an $A R(1)$ process is explicitly modeled.

Due to the interaction term, the coefficients on the macro variable and the labor market institutions index cannot be interpreted on their own. The marginal effect of macro shocks on changes in unemployment amounts to -.34 , based on the estimates in the last column of Table 2. It is almost identical to the estimated coefficient of the 'macro' variable itself. Since here, marginal effects are computed at sample means, we can conclude that for a hypothetical country with average labor market institutions, no considerable influence of institutions exist. Further calculations show that this finding holds almost uniformly across all countries. Put differently, institutions do not seem to play any significant role in shaping the adjustments of the unemployment rate to macroeconomic shocks. As a corollary, we can note that the marginal effect of institutions on unemployment is not different from zero. 
Table 2: Fixed-effects panel models using different estimators

\begin{tabular}{lrrrr} 
& $\begin{array}{c}\text { FGLS, } \\
\text { heterosked. } \\
\text { Panels }\end{array}$ & PCSE & $\begin{array}{r}\text { FGLS, } \\
\text { heterosked. } \\
\text { Panels, AR1 } \\
\text { Error }\end{array}$ & $\begin{array}{c}\text { PCSE, AR1 } \\
\text { Error }\end{array}$ \\
\hline Lagged Dependent Variable & coef/se & \multicolumn{1}{c}{ coef/se } & \multicolumn{1}{c}{ coef/se } & \multicolumn{1}{c}{ coef/se } \\
\hline Macro Shocks & $0.306^{\star \star \star}$ & $0.308^{\star \star \star}$ & $0.147^{\star \star \star}$ & $0.133^{\star \star}$ \\
& $(0.029)$ & $(0.063)$ & $(0.029)$ & $(0.058)$ \\
\hline Labor Market Institutions & $-0.255^{\star \star \star}$ & $-0.289^{\star \star}$ & $-0.307^{\star \star \star}$ & $-0.336^{\star \star \star}$ \\
& $(0.017)$ & $(0.035)$ & $(0.016)$ & $(0.030)$ \\
\hline Interaction: Shocks-Intitutions & 0.036 & 0.053 & 0.049 & 0.066 \\
\hline Bargaining Coordination & $(0.039)$ & $(0.086)$ & $(0.049)$ & $(0.098)$ \\
& -0.011 & -0.015 & -0.008 & -0.021 \\
& $(0.015)$ & $(0.019)$ & $(0.015)$ & $(0.019)$ \\
\hline
\end{tabular}

note: ${ }^{\star \star \star} p<0.01,{ }^{\star \star} p<0.05,{ }^{*} p<0.1$

These findings can be confirmed as we move on to separate models for three groups of countries based on the cluster analysis of section 3 . The estimates for the three separate models - all estimated by FGLS with corrected standard errors - are reported in Table 3. The first group, which could be termed 'Continental Europe', comprises Austria, Belgium, Finland, Germany, the Netherlands, Norway, Sweden and Switzerland. In the second column of the table, the results for the 'Anglo-Saxon' countries (Australia, Canada, Ireland, New Zealand, the United Kingdom and the United States) and Japan are given. Finally, the third column contains the regression output for the 'Southern European' group (France, Italy, Portugal and Spain). As expected from the full model, including all 20 countries, the differences of the estimated coefficients on the macro variable are not that large. Turning directly to the marginal effects the impact of macro shocks on unemployment is largest in the Anglo-Saxon countries (-0.42), followed by 'Continental Europe' (.34). But even in 'Southern Europe' the effect amounts to - 31 .

Moreover, we find large differences in the marginal effects of institutions evaluated at sample means. The effect of institutions is significant in the 'Anglo-Saxon' and the 'Southern Europe' group. While in the former institutions increase unemployment changes, they reduce them in the latter. 'Continental European' countries range somehow in between. Since the sign of the 'institutional effect' is undetermined from a theoretical point of view, this could be either due to offsetting partial effects of different labor market institutions as well as the result of a dominant role played by employment protection. The literature on labor market institutions and macroeconomic performance has stressed for a long time that employment protection has ambiguous effects. Finally, we cannot rule out the possibility that the insignificance result is due to an inappropriate clustering strat- 
egy. This can be seen from the different signs and significance levels the variable shows in the three separate regression models.

Nevertheless, with respect to our basic research question these points are only of incidental interest, since we assume by and large that labor market institutions do not react to the crisis. For this reason, we have also chosen to include the institutions variable in levels and not in deviations. Surely, institutions can and to some extent were adjusted during the crisis, but these changes are typically confined to passive labor market policies such as unemployment benefits (and in particular benefit duration) and short-time working schedules. With respect to the central research question whether and to what extent labor market institutions cause unemployment our empirical approach is not suited to provide a substantial contribution.

Comparing the three separate models with the panel including all 20 OECD countries, we note that there is heterogeneity that is not accounted for by allowing for country-specific effects. The estimated fixed effects in our models are almost always insignificant. So while there seem to be differences with respect to the slope parameters, there are no indications of country-specific trends. ${ }^{5}$ This is also a result of the rather long period of time covered by our data.

The use of the two clustering strategies - principal component analysis and separate models for different groups of countries - makes the empirical models more robust. Robustness has been an issue in the literature for many years. There have always been doubts whether the models used also hold for slight variations in specifications and data (Baker et al. 2003, 2005; Baccaro and Rei 2007). We do not find such instabilities. Our main finding, that institutions do not matter much in shaping the short-run labor market responses, holds not only for different estimation methods but also for models that include lagged variables.

\footnotetext{
${ }^{5}$ From a methodological point of view, the differences found by running separate models for the three country clusters raises the issue of 'poolability'. Nickell et al. (2005) claim that the Roy-Zellner test (see Baltagi 1995) does not reject the assumption of common slopes. This finding is clearly at odds with our experiences. We do not find econometric support for the notion of 'one model fits all'.
} 
Table 3: Regressions by country groups using PCSE, correcting for serially correlated error terms

\begin{tabular}{|c|c|c|c|}
\hline & $\begin{array}{l}\text { Continental } \\
\text { Europe }\end{array}$ & Anglo-Saxon & $\begin{array}{l}\text { Southern } \\
\text { European }\end{array}$ \\
\hline & coef/se & coef/se & coef/se \\
\hline \multirow[t]{2}{*}{ Lagged Dependent Variable } & 0.067 & -0.047 & $0.366^{\star \star \star}$ \\
\hline & (0.063) & $(0.065)$ & $(0.097)$ \\
\hline \multirow[t]{2}{*}{ Macro Shocks } & $-0.207^{\star \star \star}$ & $-0.286^{\star \star \star}$ & $-0.317^{\star \star \star}$ \\
\hline & (0.038) & $(0.048)$ & $(0.053)$ \\
\hline \multirow{2}{*}{ Labor Market Institutions } & 0.134 & $0.622^{\star \star}$ & $-0.460^{\star \star \star}$ \\
\hline & $(0.107)$ & $(0.273)$ & $(0.157)$ \\
\hline \multirow[t]{2}{*}{ Interaction: Shocks-Intitutions } & $-0.149 * \star \star$ & $0.149^{\star \star *}$ & 0.067 \\
\hline & $(0.032)$ & $(0.036)$ & $(0.078)$ \\
\hline \multirow[t]{2}{*}{ Bargaining Coordination } & $0.160^{* *}$ & -0.060 & 0.071 \\
\hline & $(0.076)$ & $(0.051)$ & $(0.072)$ \\
\hline
\end{tabular}

note: ${ }^{\star \star \star} p<0.01,{ }^{\star \star} p<0.05,{ }^{*} p<0.1$

\subsection{Dynamic Simulations}

An interesting way to assess our models is to plot the predicted changes in unemployment rates against the actual ones. The results of this exercise are depicted in Figures 6 to 8 .

Figure 6: Actual and simulated changes of unemployment rates - 'Continental Europe' group

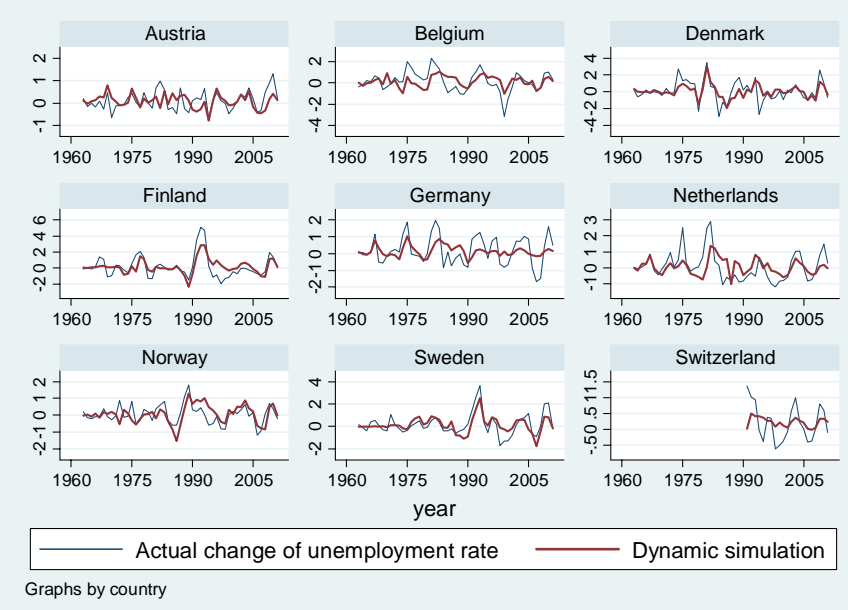


For a number of countries, the model is able to replicate changes in the unemployment rate quite well. Particularly for the Nordic countries, the model appears to produce roughly acceptable forecasts. For some other economies, the fit is rather poor. Germany, for instance, shows much more actual variation in the unemployment rate than the model predicts - this calls for a more detailed historical account. Concerning the latest figures, where our graphs plot OECD forecasts for 2010 and 2011 against predicted values, the model comes close to the actual and forecasted rates in Belgium, Finland, the Netherlands, and Norway for the first group. It also does a good job for Canada, Japan and the US for the second group.

\section{Figure 7: Actual and simulated changes of unemployment rates - 'Anglo-Saxon' group}

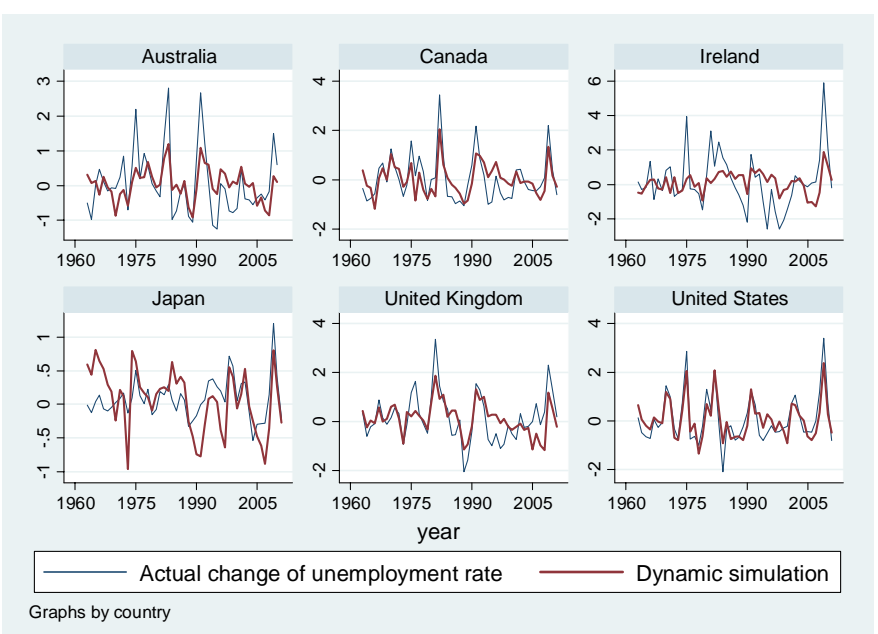

Interestingly, our models do not predict increases in national unemployment rates due to the current crisis, beyond those experienced so far or forecasted to materialize in the near future. This finding also holds for the vast majority of peaks and troughs in the past. Up to a certain level, this feature is due to the fact that a panel is fitted to population means. However, since we model country-specific shocks, which obviously differ between units of observation, there is at least the theoretical possibility - if countries are really similar in some sense - that our models come close to observed changes in unemployment. Denmark and the US are good examples that this could also hold in practice. The better fit for these two countries is likely due to the characteristics of the Danish and the American labor markets. Both countries have rather flexible labor markets - although different in nature - which react rather instantaneously to business cycle fluctuations. 
On the other hand, Germany and Switzerland, two economies that have grown at relatively small rates during the 1990s and early 2000s, do not follow the predicted slow movements in unemployment rates. This result points to other sources of variation which are not captured by our variables. In retrospect the German unemployment rate could be perceived as excessively high and volatile compared to other European labor markets. Except for changes in statistical definitions or related measures, such large deviations could also result from different economic structures or structural changes which are not captured in the macroeconomic data. Against the backdrop of the concentration of the current economic crisis on a few industries in several countries, this line of research could be taken up in future work.

Admittedly, there are signs of misspecification in the sense of failure to describe the dynamic relationship between the independent and the dependent variables. This problem is even more exacerbated when we regressed changes in employment rates, instead of unemployment rates, on our set of explanatory variables. The modeling strategy pursued here, which is very similar to the one in Nickell et al. (2005), although including the lagged dependent variable and accounting for serially correlated error terms, is obviously not capable of explaining a significant part of the persistence mechanisms at work.

Figure 8: Actual and simulated changes of unemployment rates - 'Southern Europe' group

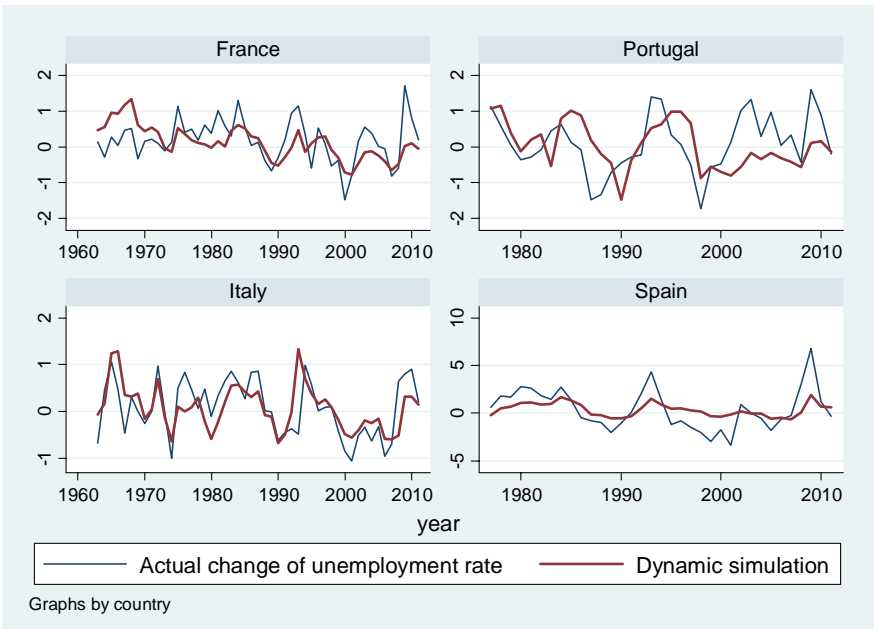




\section{Case Studies}

Case studies can help deepen the analysis by going beyond standardized aggregate institutional indicators and taking into account the complexities of political and enterpriselevel adjustment. We therefore give a more detailed account of four 'ideal types' of European economies with largely different combinations of (a) active and passive labor market policies and (b) employment protection.

Figure 8: Case selection

\begin{tabular}{|c|c|c|c|}
\hline & \multicolumn{2}{|c|}{ Employment protection (core) } \\
\hline & & Strong & Weak \\
\hline \multirow{2}{*}{ 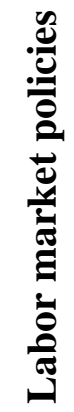 } & Large & $\begin{array}{c}1 \\
\text { (Continental corpo- } \\
\text { ratist countries, DE) }\end{array}$ & $\begin{array}{c}3 \\
\text { (Flexicurity coun- } \\
\text { tries, DK) }\end{array}$ \\
\hline & Small & $\begin{array}{c}2 \\
\text { (Mediterranean } \\
\text { countries, ES) }\end{array}$ & $\begin{array}{c}4 \\
\text { (Anglo-Saxon coun- } \\
\text { tries, UK) }\end{array}$ \\
\hline
\end{tabular}

\subsection{Germany: Employment Stability despite Strong Export Orientation}

Germany is a country which was heavily affected by the steep decline in international trade, which, in turn, led to a significant fall in orders and exports, particularly in core areas of the German production model, such as machinery and automobile manufacturing. However, despite its vulnerability due to the dependency on exports and the associated GDP decline of $5 \%$ in 2009, unemployment has basically remained stable, as has the total employment rate. Stable total employment is, on the one hand, due to the still dynamic growth in major parts of the service sector, which could offset limited losses in exportoriented sectors such as manufacturing and logistics. On the other hand, the relative success of the German story is explained by the fact that the core labor market of skilled workers in manufacturing is covered by strong legal dismissal protection - hence, shortterm adjustment does not lead to quick layoffs but is dominated by an elaborate ar- 
rangement of internal flexibility (Möller 2010, Fuchs et al. 2010, OECD 2010). Three elements are crucial:

1. First, internal flexibility: this has already increased considerably over the past two decades, both within in the framework of collective bargaining and at the level of the enterprise. Hence, working time can be adjusted flexibly via working time accounts. In fact, surpluses in these accounts and overtime declined significantly: whilst employment was virtually unchanged from late 2008 to late 2009, the total volume of hours worked declined by about 3\%. At the same time, the social partners were also allowed to adjust agreed wages or postpone wage increases in difficult times.

2. Second, the concentration of redundancies in the marginal workforce: over the past five years, manufacturing employers have increasingly relied on temporary agency staff to establish a flexible segment of the workforce which can be swiftly adjusted under uncertain economic prospects. Therefore, when the crisis began, employers started to reduce the number of agency workers active in their firms by about 300,000, so that employment decline could basically be limited to this category of workers. On a smaller scale, the same is true for the non-renewal of fixedterm contracts.

3. Third, heavy reliance on a public short-time work allowance embodied in the institutional repertoire of the unemployment insurance and active labor market policy system. In 2009, 1.1 million workers (about 350,000 full-time equivalents) worked short-time. The short-time work or partial unemployment scheme was, of course, already in place before the crisis began, but it has been modified in three aspects: (i) the maximum duration for which hours not worked are reimbursed by the unemployment fund at the regular replace rate applicable in case of unemployment was increased from six to 24 months for inflow in 2009 (18 months in 2010); (ii) for cases of short-time work arising in 2009 and 2010, employers are exempt from social security contributions for hours not worked - regarding employee contributions from the first day of short-time work, regarding employer contributions from the seventh month of reduced working time (or earlier in case of employerprovided training); and (iii) administrative requirements for firms entering this scheme were simplified considerably.

Given the abrupt character of the crisis and the uncertainty of its duration, employers have been reluctant to dismiss skilled staff as long as partial unemployment is feasible and a recovery is expected. The German fiscal stimulus package seems to have so far had a limited direct impact on the labor market outside expansion of partial unemployment schemes. Despite some measures to help stabilize consumer confidence, such as a marginal cut in income taxes and social security contributions, and a 'cash for clunkers' scheme, the fiscal package has yet to show its major impact. Most recent figures on the development of GDP and exports show early signs of recovery. Hence, the extent of employment losses may be contained, and labor market performance in 2009 and 2010 
could be better than in earlier forecasts. Hence, working time flexibility and complementary short-time work allowances could have helped bridge the slump in manufacturing without endangering the skilled core labor force.

\subsection{Denmark}

In the decade before the crisis, Denmark became a celebrated model country for the flexicurity approach. The combination of its traditionally flexible labor law, generous unemployment benefits, and active labor market policies ensured a very smooth functioning of the employment model. Thanks to this 'golden triangle', the Danish labor market was characterized by high mobility and far above-average employment rates. Unemployment was virtually non-existent.

However, the recent crisis had a comparatively strong impact on the economy and especially on the labor market. Given the excellent situation in the past, an unemployment rate of more than $6 \%$ meant a severe increase. While Denmark is still doing comparatively well, it is approaching the EU average concerning most labor market indicators.

The straightforward interpretation of this trend is that the Danish employment system features fewer internal institutional buffers against an output shock. As one would expect, liberal dismissal regulation contributes to a large inflow into unemployment during an economic crisis. On the other hand, labor market recovery should be more dynamic once the economy returns to growth, as hiring barriers are lower and activation policies are in place. Furthermore, Danish policy makers have refrained from interfering with the economy by way of sectoral subsidization.

Whether this institutional advantage of the Danish model will prove to be beneficial in the near future also depends on the second aspect of the flexicurity concept - social security and activation. The Danish welfare state provides high income replacement in the case of job loss. Even after five years of unemployment, net benefits of previous low-wage earners can amount to more than $80 \%$. This is the most generous level in the OECD (average: 45\%). To diminish disincentives to take up work, labor market reforms in previous years have strengthened the activation of the unemployed. While active labor market policies were sufficient to promote employment in normal economic times, it remains to be seen how the system will work against the background of severe unemployment. So far, Danish active labor market policies have been characterized by policy continuity - also with respect to activation strategies trying to increase labor supply.

Yet, the crisis also revealed the macro-economic advantages of high level of social protection. It can be shown that unemployment insurance had a significant effect as an automatic stabilizer in those countries with sufficient levels of income protection (e.g., vis-à-vis the United States). This holds true for Denmark in particular. Together with Austria and Sweden, the income stabilization effect of benefits is the largest in the OECD (Dolls et al. 2009). In a similar fashion, the budget available for active measures is tied to the devel- 
opment of the unemployment rate. Therefore, the Danish regime adapts automatically and needs less discretionary intervention by policy makers.

So although the crisis had a severe impact, the generous Danish welfare state helped prevent worse effects. This is an insight that should be reflected in the reform discussions of countries that traditionally refrain from implementing strong automatic stabilizers. On the other hand, these beneficial short-term effects of the welfare system imply risks in terms of labor market performance. The Danish experience has shown that the right mix of welfare state generosity and activation is crucial to reconcile both objectives. While the country has been very successful in the past, the current crisis could make further adjustments necessary.

\subsection{Spain}

Concerning the international economic crisis, the Spanish labor market is one of the hardest-hit in the European Union. In December 2009, unemployment rose to almost $20 \%$ - twice the euro zone average; within in the EU, only Latvia has comparable rates. The reason for this devastating labor market performance can be found in the features of the previous upswing as well as in the bifurcated employment model.

Before the crisis, Spain had experienced a long-lasting boom period, with above-average growth rates and strong job creation. However, both heavily relied on a housing bubble, which burst in the wake of the international crisis. Accordingly, employment losses were particularly severe in the oversized construction sector.

In addition, Spain features relatively flexible job protection regulation at the margin of the labor market. As opposed to strictly regulated permanent contracts, temporary workers form a very flexible tier in the labor market. While this pattern of asymmetric flexibility is by now quite typical for highly regulated European labor markets, Spain in this regard is an extreme case. Before the crisis, approximately one-third of all employees worked on a fixed-term contract. Educational purposes or extended probationary periods, which play a large role in other countries, are almost non-existent. Around $85 \%$ of all employees in Spain working on a temporary contract do so involuntarily. Only Cyprus, Greece and Portugal exhibit similarly high values in the EU. In addition, approximately two-thirds hold a contract with a duration of only six months or less (twice the EU-15 average).

It was mainly this segment of highly flexible workers who carried the burden of labor market adaptation in the recent recession. Between the beginning of 2007 and the end 2009, the share of temporary workers in total employment decreased from 32 to $26 \%$. The total reduction amounted to more than 1.2 million workers. At the same time, employment among permanent workers was very stable: about $90 \%$ of the jobs lost were temporary ones.

With a large fiscal stimulus package, the Spanish government contributed to keeping GDP decline moderate. However, policy measures designed to keep unemployment at bay were less successful. In an attempt to encourage German-style labor hoarding, social security 
payments were lowered for companies that reduced employees' working hours instead of dismissing them. In addition, wage subsidies for workers on short hours and subsidies for companies hiring part-time workers were created. Hence, Spanish policy makers tried to stimulate policies in favor of working time and, therefore, internal flexibility, which is seen as better alternative to excessive external flexibility stemming from fixed-term contracts. At the same time, however, policy makers also extended unemployment benefits.

A possible reason for the failure of this program to prevent unemployment from rising continuously can be found in characteristics of the workers laid-off. The jobs that were created in the upswing preceding the crisis and now no longer exist are predominantly low-productivity jobs in construction; hence, there is no interaction with existing strategies of skill-oriented internal flexibility, as can be observed in German manufacturing.

By and large, there are few incentives for Spanish employers to retain low-skilled and flexible workers (whose redundancies do not involve significant turnover costs for firms) during a phase of slump. And there is little ad-hoc policy measures can do about it. Hence, the seemingly crisis-specific problems point to more deeply rooted challenges for the Spanish employment model: to shift job-creation to sectors with higher productivity and to overcome segmentation in the labor market. Concerning the latter, the lessons of the crisis do not seem to have increased chances for reform. While there has an expansion of unemployment benefits to counter social concerns, the liberalization of dismissal laws still ranks low on the agenda.

\subsection{United Kingdom}

The United Kingdom was also heavily hit by the current crisis - but in contrast to Spain and Germany, the British economy was not affected mainly due to an oversized construction sector or heavy reliance on manufacturing. The crisis rather hit the UK as Europe's financial centre, which had benefited from a dynamic development of the banking sector and strong housing price growth for many years (Bell and Blanchflower 2009). This has been associated with a dynamic development of job creation in the private service sector. High exposure to global financial business and, at the same time, a rather flexible labor market and smaller welfare state - compared to most Continental European countries imply high labor market vulnerability. Compared with, e.g., Germany, external flexibility is more dominant than internal adjustment of firms. In accordance with a pattern dominated by external flexibility, working time adjustment did not contribute significantly to the adjustment process following the recent shock. More flexibility could be observed with wages in the private sector.

In good times, a less regulated labor market can contribute to strong employment growth; in bad times, this reduces the buffering effect of intra-organizational arrangements. At the same time, the tax/benefit system in the UK provides less automatic stabilization than in Continental European or Scandinavian countries. The increase of unemployment was stronger in the UK than it was in Germany, however, the UK performed bet- 
ter than Spain, Denmark, and the US. A more in-depth analysis shows that, at least until recently, job losses in the private sector were compensated for by a stable and ever expanding public sector. Major job cuts could be observed in the vulnerable exposed sectors such as manufacturing, finance and construction as well as distributional services.

Given the limited role of automatic stabilization and the size of the shock experienced by the British economy, it is interesting to see that the UK adopted a larger-than-average fiscal stimulus package, which helped mitigate the immediate labor market impact of the crisis and will also contribute to additional fiscal constraints in the future. At the same time, the UK is also one of the countries which implemented the most comprehensive crisis-related reforms in the realm of unemployment protection and active labor market policies. The existing institutional repertoire was expanded in order to cope with increasing unemployment and speed up reintegration into employment. In this perspective, discretionary policy making complemented active labor market instruments which were already in place at the outset of the current crisis, such as the JobCentre Plus and Rapid Response Services, to achieve a broader activation with more intensive support for all jobseekers out of work for more than six months, an activation guarantee for young people and a more general scheme implemented in fall 2009 (Flexible New Deal) replacing earlier, more selective ones. Furthermore, incentives for employers who recruit and train people unemployed for at least six months were introduced and extra funding given for training, not only for the unemployed but also for start-up support.

\section{Conclusion}

Countries vary widely with respect to the labor market impact of the current global economic crisis. Macroeconomic shocks and policies, institutional factors and policy packages interact. While the GDP shock and the structure of the economy, i.e., the share of exposed and therefore vulnerable sectors, determine the problem pressure, fiscal packages, institutional arrangements, and labor market-related policies can help explain the actual impact the crisis has in a given national context. But classical (external) labor market institutions cannot explain everything; and this is certainly confirmed by our regression models. There seems to be, however, some support in the data that institutions matter. The importance of institutions differs between countries. There are also signs that they vary between different periods of time. Since our models are rather parsimonious, we consider our results encouraging. There are, however, some obvious shortcomings. Firstly, we have so far not been able to include all margins of flexibility. The variables we used for the econometric work can be linked to external numerical as well as wage flexibility. They do not contain information about other forms of flexibility. This is an obvious shortcoming. Due to the difficulties in gathering adequate data for a large set of countries, we remain skeptical whether this shortfall could be overcome in the near future. Another related issue is the question of universality. Are the effects of labor market institutions really the same across the OECD or some subsets of countries? Finally, measurement of institutions is certainly an issue, but this has long been discussed in the literature. 
Economies which were able to rely on strong internal flexibility have hitherto been able to avoid a major increase of unemployment. Here, the core of the labor market is protected by relatively strict employment protection and benefits from working time adjustment that compensates for layoffs. This holds in particular for Germany, where working time accounts and complementary short-time work allowances helped stabilize the manufacturing sector. It comes as no surprise that many countries expanded or introduced shorttime work schemes in order to stabilize existing jobs during a crisis perceived as a transitory one. Short-time work programs allow for a smooth short-term adjustment, but also mean a costly bet on a quick recovery.

However, even in highly regulated labor markets with elaborate systems of internal flexibility, non-standard workers exhibit a much stronger risk of being made redundant during a crisis. Hence, the burden of adjustment in the current downturn is distributed rather unequally and tends to deepen dualisation in the labor market. This is particularly apparent in the case of Spain, where the termination of temporary contracts is a major channel of adjustment. Non-standard workers not only face a higher risk of unemployment, but they also tend to be less well protected by social insurance. However, policy makers in some countries have taken the initiative to ease access to benefits for non-standard workers or to increase generosity. One lesson from the crisis could be to move towards more equal distributions of risks and appropriate social protection by making benefit systems more universal, so that non-standard workers are not disadvantaged twice: in terms of employment stability and in terms of social benefits.

Welfare states not only provide income replacement for individuals, they also stabilize the whole economy. Automatic stabilizers, embodied in a progressive tax system and social benefit arrangements, have certainly contributed to the mitigation of the direct impact of the crisis on the economy. Social policies in place at the beginning of the crisis can set in immediately after the shock. Automatic stabilization policies are, therefore, much easier to implement than discretionary measures, which tend to create greater challenges in terms of appropriate implementation and often can only become effective after a certain time lag. Hence, it seems desirable for the future to have proper automatic stabilization policies (unemployment protection and active labor market policies) in place in order to limit the necessity for discretionary action. A review of policy initiatives during the crisis also shows that most discretionary changes in social and labor market policies were tied to existing programs and changed them in a parametric way (e.g., expansion of short-time work, more generous unemployment benefits or hiring subsidies, and more training or job search assistance) rather than introducing completely new elements.

Keeping unemployment low by means of internal flexibility and complementary public support, as well as automatic or discretionary policy interventions, may be a good thing in the short run. At some point, however, a cyclical crisis may turn into a structural one which requires a different policy approach: in particular, policies to cope with structural change. While many policy instruments implemented in the current situation were de- 
signed to bridge a temporary loss of demand based on the assumption that we were facing a short, but harsh, business slump, a decline of employment in manufacturing, construction or the financial sector may become inevitable in many countries if productive employment in these sectors is not viable at the pre-crisis level in the foreseeable future. If structural change is accelerated the longer the crisis lasts, well-designed policies should refrain from trying to preserve non-sustainable jobs and postpone structural change by means of sectoral subsidies. This would rather call for a timely exit from crisis-related subsidies and stabilization measures and for stronger policy action to stimulate economic innovation and mobility in the labor market. External flexibility and job reallocation gain in importance. Encouraging internal functional flexibility through lifelong learning and workplace-related training is one thing. Mobility from shrinking or declining firms and sectors to other more dynamic sectors and employers is a second major challenge, as productive employment is essential not only for individual incomes but also for the public budget and the sustainability of social policies. Welfare states and social benefits, while helpful in providing income support and buffering the immediate shock, could create work disincentives and run the risk of persistent unemployment or inactivity. They have to be complemented by active labor market policies and activation approaches encouraging quick and sustainable reemployment in the early stage of unemployment. The country studies have so far shown that there is no major rollback of activation policies; rather, more emphasis is put on active labor market policies, job search assistance and training, as well as on hiring subsidies and start-up grants. In this respect, countries can benefit from earlier reforms directed towards activation and an effective delivery of labor market policies and public employment services.

\section{References}

Amable, B. (2003): The Diversity of Modern Capitalism. Oxford, Oxford University Press.

Atkinson, J. (1985): Flexibility, Uncertainty and Manpower Management: IMS Report 89, Brighton, Institute of Manpower Studies.

Baccaro, L./ Rei, D. (2007): "Institutional determinants of unemployment in OECD countries: Does the deregulatory view hold water?" International Organization 61 (3), 27-569.

Baker, D./ Glyn, A./ Howell, D.R./ Schmitt, J. (2003): "Labor market institutions and unemployment: A critical assessment of the cross-country evidence," Oxford University Department of Economics Discussion Paper 168.

Baker, D./ Glyn, A./ Howell, D.R./ Schmitt, J. (2005): "Labor market institutions and unemployment: A critical assessment of the cross-country evidence," in Fighting Unemployment: The Limits of Free Market Orthodoxy, edited by D.R. Howell, Oxford, Oxford University Press, 72118.

Baltagi, B. (1995): Econometric Analysis of Panel Data, Chichester, John Wiley and Sons.

Bassanini, A. P./ Duval, R. (2006): "Employment patterns in OECD countries: Reassessing the role of policies and institutions," OECD Economics Department Working Paper 486. 
Bassanini, A./ Duval, R. (2009): "Unemployment, institutions, and reform complementarities: Reassessing the aggregate evidence for OECD countries," Oxford Review of Economic Policy 25 (1), 40-59.

Beck, N./Katz J. N. (1995): "What to do (and not to do) with time-series cross-section data," American Political Science Review 89: 634-647.

Bell, D.N.F./ Blanchflower, D.G. (2009): "What should be done about rising unemployment in the UK," IZA Discussion Paper 4040.

Belot, M./ van Ours, J.C. (2001): "Unemployment and labor market institutions: An empirical analysis," Journal of the Japanese and International Economies 15 (4), 403-418.

Blanchard, O. (2006): "European unemployment: The evolution of facts and ideas," Economic Policy 21 (45), 5-59.

Blanchard, O./ Wolfers, J. (2000): "The role of shocks and institutions in the rise of European unemployment: The aggregate evidence," The Economic Journal 110 (462), 1-33.

Daveri, F./ Tabellini, G.E. (2000): "Unemployment, growth and taxation in industrial countries," Economic Policy 15 (30), 47-104.

Dolls, M./ Fuest, C./ Peichl, A. (2009): "Automatic stabilizers and economic crisis: US vs. Europe," IZA Discussion Paper 4310.

Eichhorst, W./ Feil, M./ Braun, C. (2008): "What have we learned? Assessing labor market institutions and indicators," IZA Discussion Paper 3470.

Eichhorst, W./ Marx, P./ Tobsch, V. (2009): "Institutional arrangements, employment performance and the quality of work," IZA Discussion Paper 4595.

Freeman, R.B. (2000): "Single peaked vs. diversified capitalism: The relation between economic institutions and outcomes," NBER Working Paper 7556.

Fuchs, J./ Hummel, M./ Klinger, S./ Spitznagel, E./ Wanger, S./ Zika, G. (2010): "Entwicklung des Arbeitsmarktes 2010: Die Spuren der Krise sind noch länger sichtbar," IAB Kurzbericht 3/2010.

Hall, P.A./ Soskice, D. (2001): "An introduction to varieties of capitalism, " in Varieties of Capitalism: The Institutional Foundations of Comparative Advantage, edited by P.A. Hall and D. Soskice, Oxford, Oxford University Press, 1-68.

Hasselpflug, S. (2005): "Availability criteria in 25 countries," Ministry of Finance Denmark Working Paper 12/2005.

Howell, D.R./ Baker, D./ Glyn, A./ Schmitt, J (2007): "Are protective labor market institutions at the root of unemployment? A critical review of the evidence," Capitalism and Society 2 (1), 1-71.

Layard, R./ Nickell, S./ Jackman, R. (1991): Unemployment: Macroeconomic Performance and the Labour Market, Oxford, Oxford University Press.

Layard, R./ Nickell, S./ Jackman, R. (2005): Unemployment: Macroeconomic Performance and the Labour Market, $2^{\text {nd }}$ edition with new introduction, Oxford, Oxford University Press.

Möller, J. (2010): "The German labor market response in the world recession - de-mystifying a miracle," Zeitschrift für Arbeitsmarktforschung 42 (4), 325-336.

Nickell, S. (1997): “Unemployment and labor market rigidities: Europe versus North America," Journal of Economic Perspectives 11 (3), 55-74. 
Nickell, S./ Nunziata, L./ Ochel, W. (2005): "Unemployment in the OECD since the 1960s. What do we know?" The Economic Journal 115 (500), 1-27.

OECD (2006): OECD Employment Outlook 2006, Paris.

OECD (2008): OECD Education at a Glance 2008: OECD Indicators, Paris.

OECD (2009a): OECD Employment Outlook 2009, Paris.

OECD (2009b): OECD Education at a Glance 2009: OECD Indicators, Paris.

OECD (2009c): OECD Benefits and Wages 2009: OECD Indicators, Paris.

OECD (2009d): OECD Taxing Wages 2009: OECD Indicators, Paris.

OECD (2010): OECD Economic Surveys Germany, Paris.

Venn, D. (2009): "Legislation, collective bargaining and enforcement: Updating the OECD employment protection indicators," OECD Working Paper 89.

Visser, J. (2009): Database on Institutional Characteristics of Trade Unions, Wage Setting, State Intervention and Social Pacts in 34 Countries between 1960 and 2007. Amsterdam Institute for Advanced Labour Studies (AIAS). 
Annex 1: Channels of flexibility and associated indicators

\begin{tabular}{|c|c|c|c|c|}
\hline $\begin{array}{l}\text { Sub- } \\
\text { Indicators }\end{array}$ & $\begin{array}{l}\text { Institu- } \\
\text { tion }\end{array}$ & Variables & Source (2003) & Source (2008) \\
\hline \multirow{4}{*}{$\begin{array}{l}\text { External- } \\
\text { Numerical }\end{array}$} & $\begin{array}{l}\text { Empl. } \\
\text { Protec- } \\
\text { tion }\end{array}$ & $\begin{array}{l}\text { Summary Indicator of EPL Strin- } \\
\text { gency }\end{array}$ & OECD & Venn (2009) \\
\hline & \multirow{2}{*}{$\begin{array}{l}\text { Benefit } \\
\text { System }\end{array}$} & $\begin{array}{l}\text { Net Replacement Rates } \\
\left(1^{\text {st }} \text { and } 60^{\text {th }} \text { month }\right)\end{array}$ & OECD & $\operatorname{OECD}(2009 c)$ \\
\hline & & Strictness of Available Criteria & $\begin{array}{l}\text { Hasselpflug } \\
(2005)\end{array}$ & $\begin{array}{l}\text { Hasselpflug } \\
(2005)\end{array}$ \\
\hline & Taxation & Tax Wedge & OECD & OECD (2009d) \\
\hline \multirow{3}{*}{$\begin{array}{l}\text { External- } \\
\text { Functional }\end{array}$} & ALMP & ALMP Spending & OECD & OECD.Stat \\
\hline & \multirow{2}{*}{$\begin{array}{l}\text { Educa- } \\
\text { tion }\end{array}$} & Educational Attainment & OECD & OECD (2009b) \\
\hline & & Expenditure per Student & OECD & OECD (2009b) \\
\hline \multirow{3}{*}{ Wage } & \multirow{3}{*}{$\begin{array}{l}\text { Wage- } \\
\text { setting }\end{array}$} & Coll. Bargaining Coverage Rate & OECD & Visser (2009) \\
\hline & & Coll. Bargaining Co-Ordination & OECD & Visser (2009) \\
\hline & & Wage-Dispersion & OECD & $\operatorname{OECD}(2009 a)$ \\
\hline \multirow{3}{*}{$\begin{array}{l}\text { Internal- } \\
\text { Numerical }\end{array}$} & \multirow{3}{*}{$\begin{array}{l}\text { Working } \\
\text { Time }\end{array}$} & $\begin{array}{l}\text { Dominant Response to Work- } \\
\text { load }\end{array}$ & ESWT & - \\
\hline & & $\begin{array}{l}\text { Rationale for Using Flexible } \\
\text { Working Hours }\end{array}$ & ESWT & - \\
\hline & & Working Time Accounts & ESWT & - \\
\hline \multirow{4}{*}{$\begin{array}{l}\text { Internal- } \\
\text { Functional }\end{array}$} & \multirow{2}{*}{$\begin{array}{l}\text { Internal } \\
\text { Qualifi- } \\
\text { cation }\end{array}$} & $\begin{array}{l}\text { Incidence of Training Provided } \\
\text { by Employer }\end{array}$ & EWCS & - \\
\hline & & $\begin{array}{l}\text { Volume of Non-Formal Job- } \\
\text { Related Training }\end{array}$ & OECD (2008) & - \\
\hline & \multirow{2}{*}{$\begin{array}{l}\text { Work } \\
\text { Organiza- } \\
\text { tion }\end{array}$} & Incidence of Task Rotation & EWCS & - \\
\hline & & $\begin{array}{l}\text { Necessity of Learning New } \\
\text { Things }\end{array}$ & EWCS & - \\
\hline
\end{tabular}


Annex 2: Structure of the composite indicator with scores for sub-indicators (circled numbers)

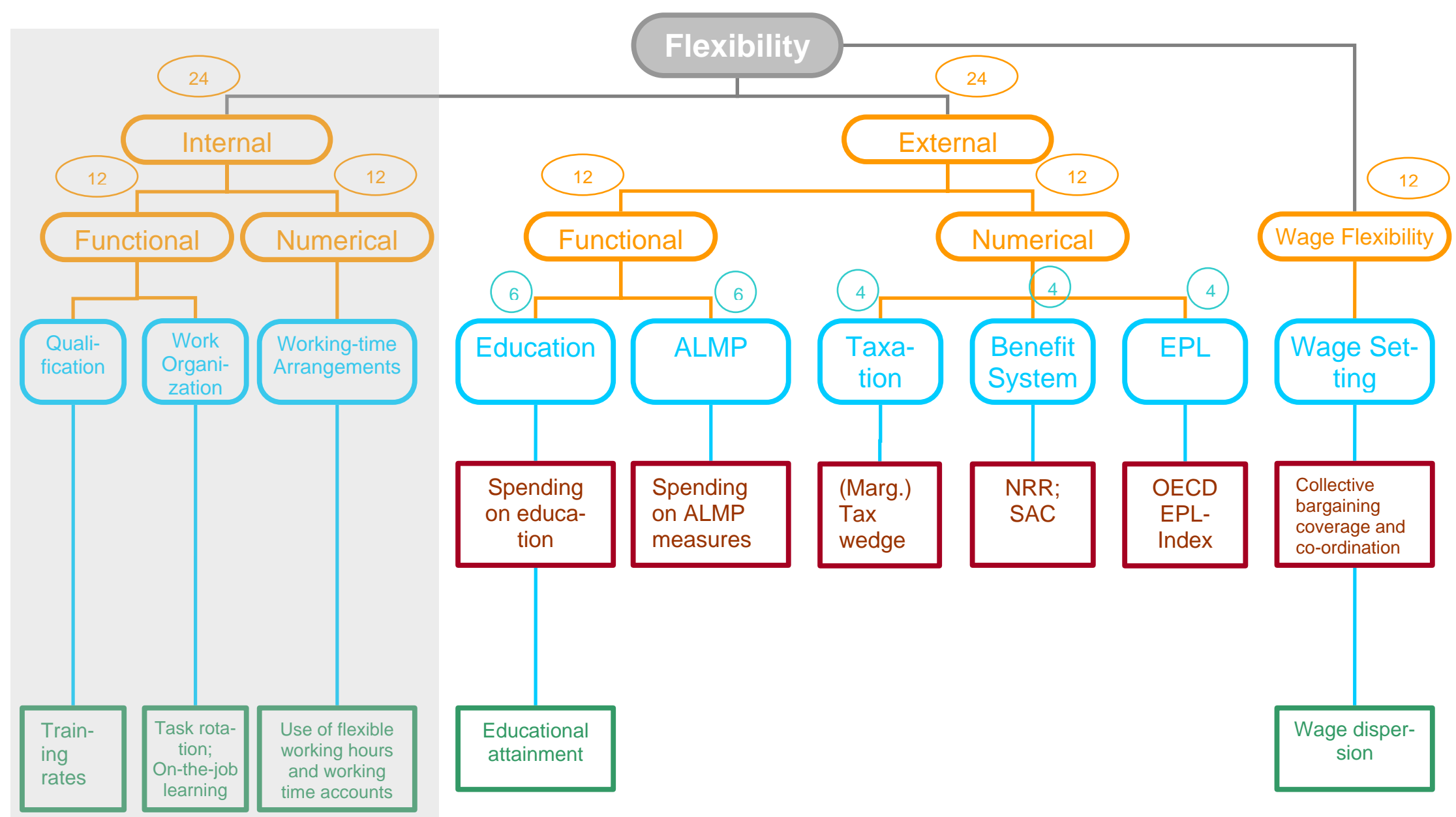

